Anita Avramides, 'Wittgenstein and Ordinary Language Philosophy', forthcoming in H.-J. Glock \& J. Hyman eds. 'Blackwell Companion to Wittgenstein', Wiley Blackwell.

\title{
WITTGENSTEIN AND ORDINARY LANGUAGE PHILOSOPHY
}

Here are three characterizations of ordinary language philosophy:

A loosely structured philosophical movement holding that the significance of concepts, including those central to traditional philosophy...is fixed by linguistic practice (Heil, 1995, p. 551)

A method of doing philosophy rather than a set of doctrines. It is diverse in its methods and attitudes. It belongs to the general category of analytic philosophy.... (Martinich, 1998, p 143)

The label 'ordinary language philosophy' was more often used by the enemies than by the alleged practitioners of what it was intended to designate. It was supposed to designate a certain kind of philosophy that flourished, mainly in Britain and therein mainly in Oxford, for twenty years or so, roughly after 1945" (Warnock, 1998, p. 147)

I shall take it that it is as much a question how we understand 'ordinary language philosophy' as it is a question how we are to understand Wittgenstein's relationship to it. Had this paper been written roughly before the turn of the $21^{\text {st }}$ century, and so closer to the time when many of the philosophers under discussion here still roamed the philosophical landscape, it would very likely have had a rather simpler structure. The question of how we understand the work of at least some of those who are often characterized as ordinary language philosophers has taken an interesting turn in recent years. And while there have always been interesting questions to be addressed when considering Wittgenstein's relationship to this school or movement in philosophy, work in more recent times has opened up important and interesting new avenues of exploration in this connection.

All three characterizations of ordinary language philosophy (OLP) given above bring out an important aspect of it: The first identifies language - or linguistic practice - as of central concern. The second reminds us that we should see those labelled as 'ordinary language philosophers' as proposing a method and as adopting an attitude as opposed to setting out a doctrine or set of doctrines. It also informs us that OLP belongs to that larger movement referred to as 'analytic philosophy'. The third explains that this style of philosophy flourished largely in Oxford during the period from, roughly, 1945 until the mid-1960's (and, thus, is sometimes referred to as "Oxford Philosophy"). It also suggests that the very name of this movement was the work of those hostile to it, indicating that this way of proceeding in philosophy while attractive to some, was vigorously rejected by others. At the heart of the very business of philosophy lies the question how we are to understand the business of philosophy: what is its method and how should it proceed? These questions received a very particular definition around the early-to-mid $20^{\text {th }}$ century.

When one looks back on the history of philosophy, there are periods - some of them relatively prolonged - where there is general agreement about the business of 
philosophy. But from around the mid-to-late $19^{\text {th }}$ century one sees certain upheavals and partings of the way. From common roots in Kant's writings one sees philosophy on the continent proceed in one direction (the phenomenological movement) while in Britain proceed in quite another (the analytic movement). The origin of analytic philosophy is itself a controversial matter. Michael Dummett has argued that the sources of analytical philosophy were the writings of philosophers who wrote, principally or exclusively, in the German language, in the work of such philosophers as Husserl, Bolzano, Brentano, Meinong and Frege (see Dummett, 1993, ix). Dummett has largely concentrated his efforts on explaining Frege's contribution to the origins of analytical philosophy, and to that moment which many take to characterize it: the linguistic turn. Dummett claims that the linguistic turn occurs in Frege's Die Grundlagen der Arithmetik of 1884, when Frege raises the Kantian question, "How are numbers given to us, granted that we have no idea or intuition of them?" Frege's answer to this question relies on his celebrated context principal which is formulated in terms of an enquiry into language rather than into modes of thought: it is only in the context of a sentence that a word has meaning. With this principle Dummett takes Frege to have turned an epistemological enquiry into a linguistic one - sweeping aside a tradition initiated by Descartes and ushering in a new era in philosophy. The analytical era takes from the work of Frege its most fundamental tenet: that a philosophical account of thought can be attained through a philosophical account of language. Dummett gives Frege the title of "grandfather of analytic philosophy", while identifying Bertrand Russell and G.E. Moore as "uncles" (Dummett, 1993, p. 171). Russell and Moore pursued their analytical philosophy in Cambridge, where they were joined by Wittgenstein. Wittgenstein's Tractatus logicphilosophicus has been characterized by Peter Hacker as a form of critical philosophy that accepts the Kantian task of circumscribing the bounds of thought while taking a most unKantian - linguistic - point of departure. (cf. Tractatus 4.0031: "All philosophy is a 'Critique of language'.") Somewhat at odds with Dummett's interpretation, Hacker suggests that it was Wittgenstein's Tractatus that engendered the 'linguistic turn' characteristic of twentieth century analytic philosophy (see Hacker, 1997, p. 3).

Early analytic philosophy was associated with logical positivism. According to von Wright (1982, p. 108), the Tractatus made Wittgenstein one of the "spiritual fathers" of logical positivism. This may be because many read that work as, in the words of Hacker, "the swan-song of metaphysics", and the rejection of metaphysics was a major tenet of logical positivism (Hacker, 2001, p. 330). The logical positivists agreed with David Hume that philosophy which contains neither abstract reasoning concerning quantity or number nor experimental reasoning concerning matters of fact and existence should be committed to the flames because it must contain "nothing but sophistry and illusion" (Hume, 1975, p. 165). "Sophistry and illusion" also summed up the positivist attitude towards the metaphysics that they saw as being practiced largely in Continental Europe in the $19^{\text {th }}$ and early $20^{\text {th }}$ centuries. Many early analytic philosophers joined forces with these logical positivists in their combat against metaphysics, and they also embraced the logical positivist enthusiasm for science and logic. However, while these analytic philosophers turned their attention to language, the turn was not yet to ordinary language. In fact these analytic philosophers are often found denouncing ordinary language, expressing their frustration with its vagaries and imprecision. In the place of ordinary language, they promoted the development and 
study of ideal or formal languages, languages that answer to the rigours of logic and science - language abstracted from its daily use.

Thus one finds a divide developing within early analytical philosophy. While all analytic philosophers can be taken to be united in their rejection of the "the deep paradoxes and mystery mongering of their continental contemporaries" and while all were hostile "to the lofty, loose rhetoric of old-fashioned idealism" (Warnock, 1998, p. 147), they were divided in their approach to the study of language. Just as some early analytic philosophers turned away from metaphysics and towards ideal language, others can be seen to turn away from metaphysics and the ideal language of logic and science. These analytic philosophers argued that imprecision and ambiguity are of the essence of the expressive power of language and they insisted that language cannot be studied in abstraction from its daily use. They emphasized a more humanistic attitude, central to which was a deep respect for language as it is used in its everyday context. These are the so-called "ordinary language philosophers".

Among the philosophers associated with OLP, J.L. Austin holds a particular place. Oswald Hanfling suggests that, more than anyone else, it is Austin who has come to be regarded as "the archetypical ordinary language philosopher" (Hanfling, 2000, p. 26). Hanfling also suggests that Austin was fascinated by words and their meanings quite apart from their relevance to problems in philosophy. Indeed, Austin writes that his work may be seen in times to come as the beginning of "a true and comprehensive science of language" (1979, p. 232). Once this science has been established, Austin believes that "we shall have rid ourselves of one more part of philosophy" (ibid). What Austin has in mind here can, perhaps, be made clearer if we consider a metaphor that he offers (Ibid). Austin suggests that when we consider the history of human inquiry we can consider philosophy to have a place akin to the sun's place in the solar system: just as the sun throws off parts of itself that cool and progress in a well-regulated manner towards being a planet, so philosophy throws off parts of itself (e.g. mathematics, and physics) that come in time to "take up station as a science" (ibid). In so far as Austin is to be regarded as an ordinary language philosopher, these remarks suggest that he is willing to think of such a philosophy as an early moment in the birth of a new science.

Other ordinary language philosophers may be considered more philosophical in their interests in language. The list here includes Gilbert Ryle and John Wisdom. Some would also include P.F. Strawson, while others add H.P. Grice (although there is good reason to doubt that this is correct). According to Warnock, the presence of Wittgenstein "broods, so to speak, over the group" (Warnock, 1998, p. 149). The question of Wittgenstein's relationship to this group is complex. Firstly, it should be clear that in so far as Wittgenstein's work is associated with this movement in philosophy, it is the work he produced in the 1930s and 1940s. After a lengthy break from philosophy, Wittgenstein returned to philosophy and to Cambridge in 1929 and began to develop a new approach to his thinking in philosophy (how new is not an issue I shall engage with here, although I shall come back to the question at the end of this paper). Central to this new approach is the attitude taken towards language. While in his earlier work Wittgenstein sought to discover a rigid logical structure within language, he sought in his later work to let language off that leash. Wittgenstein's later attitude is that we must not constrain language but simply observe it. 
David Pears describes Wittgenstein's later work as "full of perfectly detailed descriptions of language, which are presented dialectically in a way that invites the reader to take part in the dialogue" (Pears, 1971, p. 14). Observing language in use while using it, one might say. This may be the work of an analytic philosopher, but it is no longer work that can be aligned with that of Frege, Russell and Moore. Russell himself firmly rejected Wittgenstein's later work as "a trivial investigation of language" (Ibid, p. 19).

This rejection by some of Wittgenstein's later work has been taken to mark an important moment in the divide between analytic philosophers. While many Cambridge philosophers were distancing themselves from Wittgenstein's new work, many Oxford philosophers were embracing it. These Oxford philosophers saw Wittgenstein's new work as at one with what they were practicing. Austin, for example, writes that language is a long-evolved, complex and subtle instrument and advises that philosophers should afford it careful scrutiny. He points out that language has evolved over many generations and that the distinctions made within it and the connections marked by it "have stood up to the long test of time of the survival of the fittest" and are "more subtle...than any you or I are likely to think up in our armchairs of an afternoon" (Austin, 1979, p. 182). Austin acknowledges that ordinary language has no claim to be the last word in philosophy, but he insists that it would be prudent at least allow it the first word (Ibid, p. 185). Referring to ordinary language, Austin remarks in his characteristically lively manner: "too evidently, there is gold in them thar hills" (Ibid, p. 181). This attitude which can be identified in Austin's work is sometimes taken to be the central credo of the ordinary language group. We can compare what Austin writes here with what Wittgenstein writes in Zettel: 'Philosophy turns our attention to the use of words' (§463).

It is clear that certain ideas are in the air, and the air is breathed in by many in Oxford and some in Cambridge. I leave it to the scholars to identify the details of influence. What I can record is that Wittgenstein, while living and working in Cambridge, is said to have regarded Oxford as a "philosophical desert" (Warnock, 1978, p. 148).

Warnock also tells us that, while the substance of Wittgenstein's later work was akin to that going on in Oxford, "the characteristic cool, ironic urbanity of manner was odious to him". Warnock concludes that Wittgenstein would have "furiously disclaimed any kinship" with the ordinary language philosophers of his day (Ibid). McGinn and Kuusela remind us that Wittgenstein rejected the idea of parties and taking sides in philosophy but explain that they can see why those identified as ordinary language philosophers "would have wanted to claim a powerful mind such as the later Wittgenstein to be on their side" $(2011,6)$. Dummett goes so far as to write (admittedly in a rather bad tempered review of Ernest Gellner's Words and Things) that "Wittgenstein's later philosophy is totally distinct both from logical positivism and from the ordinary-language movement" (Dummett, 1978, p. 433). In another place Dummett writes in a more even-tempered manner that "the doctrines of 'ordinary language philosophy' were a caricature, but not a gross caricature, of the views of the later Wittgenstein" (1978, p. 445).

From all this we may conclude that one needs to separate out the question of whether Wittgenstein would himself have identified his work with OLP from the question whether those who are identified as ordinary language philosophers would claim Wittgenstein as an ally. Separate from both of these is the question whether there is a 
tendency on the part of many to amalgamate the work of these philosophers. This is clearly the case. This tendency can be attributed as much to those who champion this work as to those who are hostile to it, but I am inclined to believe that it is largely the work of the latter group. According to those who rejected the work being done both by the likes of Austin and Ryle and by Wittgenstein there was a tendency to cast Wittgenstein as a heresiarch and Austin as a pedant (see Warnock 1998, p. 149)

Perhaps it would be best simply to agree that the impact of the later Wittgenstein's philosophy was coincident with the influence of ordinary language philosophy and that this can in part be attributed to certain overarching ideas shared by both. While there are important differences amongst those classified as ordinary language philosophers, for those who are hostile they do not matter. As indicated earlier, there is a rejection by all those classified as ordinary language philosophers of the idea that philosophy is in the business of constructing grand metaphysical systems. According to OLP - and here one need not hesitate to include Wittgenstein's name - there is a tendency to be misled by language into metaphysical pseudo-profundities. Pears explains that what Wittgenstein tries to do is to teach us to resist the enchantment of language which tempts us to accept the pictures associated with metaphysics and other philosophical errors (Pears, 1971, p. 16). Austin, too, advises that we need to be careful about our use of words - we must "examine what we should say when" and thereby "forearm ourselves against the traps that language sets us" (Austin, 1979, pp. $181-182$ ). Thus we find that in as much as we are to pay attention to the uses of language, we should not accept everything we ordinarily say blindly or without careful consideration. One area where Wittgenstein believes we are led astray by language is when thinking about the mind. There is, for example, a certain asymmetry recorded in our language concerning what we feel in our own case and what we observe in the case of another when we say, "I know what I mean by 'toothache' but the other person can't know it" (Wittgenstein, 1968, 276). Wittgenstein notes that we observe this asymmetry and we "look on this as a mirror image of the nature of things" (Ibid ,p. 277). There is no doubt that this is how some philosophers reason.

Wittgenstein comments: "But if you look closer you will see that this is an entire misrepresentation of the use of the word "toothache" (Ibid, p. 281). We have allowed ourselves to be bewitched by language. Marie McGinn observes that, for Wittgenstein, language is "both the source of philosophical problems and the means to overcome them" $(1997,12)$.

In PI 114 Wittgenstein refers explicitly to the Tractatus, and writes, as though speaking to his earlier self: "One thinks that one is tracing the outline of the thing's nature over and over again, and one is merely tracing round the frame through which we look at it." The frame to which he refers is the frame of language, and what our language does is frame a picture that holds us captive (cf. PI 115). So language can be the source of the problem but, if we are careful, language can also be the means to overcome our problems. What we will find is that: "The confusions which occupy us arise when language is like an engine idling, not when it is doing work" (PI 132). In PI 116 Wittgenstein writes the lines that some have pointed to as evidence of his standing as an OLP: "What we do is try to bring words back from their metaphysical to their everyday use" (auf ihre alltägliche Verwendung). It is agreed by all who read Wittgenstein that these words are designed to turn us away from metaphysics. Whether they are words designed us to turn us in the direction of ordinary language is disputed, as we shall see below. 
The turn away from metaphysics that one finds in the work of Wittgenstein and OLP is connected with the idea - expressed particularly well by Wittgenstein - that the study of language should content itself with surveying what lies on the surface. The philosopher runs into problems and difficulties when s/he does not rest content with this surface, but insists on trying to reach beyond our words to something that "lies beneath the surface" (PI 92). We insist on trying to understand what we take to be "the essence of language", and we take it that such understanding will tell us something about the essence of the world (whether, for example, it is to be understood as the realist thinks or the idealist); we are led back to metaphysics. Where philosophers tend to strive to understand by amassing generalities which lead ultimately to pronouncements about the nature of the things, Wittgenstein advises that we simply observe what we do (cf. 1958a, pp. 19-20). Rather than start with the question, What is language? - anticipating a reply that can settle the question once and for all and independently of any future experience - Wittgenstein asks us to "simply look and see" how we use language (PI, 93). From time to time we find Wittgenstein commenting on his own earlier views of language, of his own tendency to turn away from natural and towards ideal languages. In PI 107 he explains that we want to understand what we take to be the hidden essence of language, and we find that the examination of "actual language" (die tatsächliche Sprache) does not yield this. In reaction, we decide to move in the direction of logic and an ideal language in order to achieve the understanding we seek. He comments (PI 210): "We have got onto slippery ice where there is no friction and so in a certain sense the conditions are ideal, but also, just because of that, we are unable to walk. We want to walk: so we need friction. Back to the rough ground!" The rough ground is to be found in die tatsächliche Sprache, in die Sprache des Alltags.

At the point at which Wittgenstein asks us to observe what we do with language he insists that we rest content with descriptions and eschew explanations: "Philosophy may in no way interfere with the actual use of language; it can in the end only describe it" (PI 124). Here we find Wittgenstein introducing a certain attitude towards the business of philosophy, and it appears to be different from the business of science. In PI 126 he writes, "One might also give the name "philosophy" to what is possible before all the new discoveries and inventions". And in PI 128 Wittgenstein tells us that it is not the business of philosophy to advance theses. Pears writes of the "new philosophy" - which he attributes to both Wittgenstein and OLP- and tells us that its "method is always to bring us back to the linguistic phenomenon" (Pears, 1971, p. 16). This method has been characterized as "piecemeal" (Bernard Williams) or "plodding if necessary" (G.E. Moore) (Warnock, 1998, p. 149). Austin also warns philosophers not to bite off more than they can chew. This piecemeal method often manifested itself in an hostility to philosophical theories, systematic examinations and general conclusions.

In a paper devoted to exploring the question of whether analytical philosophy can - or ought to be - systematic, Dummett tells us that "in those English philosophical circles dominated by the later Wittgenstein and Austin [...] the answer given to this question is a resounding 'no'; for them, the attempt to be systematic in philosophy was the primal error, founded upon a total misconception of the character of the subject" (1978, p. 438). This attitude manifested itself somewhat differently in the work of Austin and that of the Wittgenstein. As Dummett reads Wittgenstein, the resistance to 
systematisation in philosophy is connected to a particular view about the nature of philosophy. Dummett understands Wittgenstein to advocate a fundamental difference between the business of philosophy and the business of science - and Dummett tells us that we are here to understand "science" in the most general sense, as embracing "any discipline (art history, for example) whose aim is to arrive at and establish truth" (Ibid). In the place of establishing truths what Wittgenstein urges is that philosophy should be thought of as aiming "to substitute a clear vision for a distorted one", a vision which will reveal a "familiar fact known to everybody" (Ibid, p. 439). Not all philosophers would agree that Wittgenstein opposes systematisation in philosophy, as I explain below.

Dummett also finds a resistance to systematisation, especially of language, in Austin's work. He reminds us that Austin repeatedly urges philosophers to collect particular facts about our language use (Dummett, 1978, p. 440). This observation of Dummett's, however, needs to be balanced against the fact that Austin does not contrast the business of science and philosophy. Perhaps we can paraphrase what Austin says about OLP (see above) and say that philosophy may be the first, but it may not be the last, word. We should note that Austin acknowledges that psychology, for example, produces novel cases and it also produces new methods for bringing the phenomenon under study, and he tells us that such work may require that we revise the classifications of ordinary life - the classifications embodied in ordinary language and studied by philosophy (Austin, 1979, p. 186).

What we can say is that Wittgenstein and the ordinary language philosophers turn their attention to the particular use of particular sentences and that this turn is connected with a tendency on the part of these philosophers to disregard any distinction between semantics and pragmatics, between the literal meaning of our words and what someone may choose to convey by uttering them (cf. Dummett, 1978, p. 445; cf . also Grice, 1989). The idea of literal meaning was sometimes rejected by these philosophers as yet another attempt at generalization and theory building in philosophy. Attention to the use we make of words in our ordinary speech thus came to be seen as deeply threatening to much work in philosophy. Indeed, it came to be seen as a threat to much of the business of philosophy as it was being practiced around that time.

According to Hacker, Wittgenstein "thought of himself in 1931 as the destroyer of the great tradition of Western philosophy" $(2007,102)$, and as developing a "new subject" (2001, p. 332). This new philosophy "is above all an activity, not a body of doctrine" (Ibid, p. 332-333). Hacker writes that for the later Wittgenstein philosophy can be taken to have "a double aspect" (2001, p. 324). On the one hand we can think of it as a kind of therapy for diseases of the understanding, for the conceptual entanglements to which we are prone. According to Hacker, this aspect of philosophy has a "negative tenor" which he takes to be "counterbalanced by the more positive notion of attaining a survey of philosophically problematic domains of grammar" (Ibid, p. 333). Hacker takes Wittgenstein - along with many of the ordinary language philosophers - to be interested in what sometimes gets called "conceptual geography". Hacker writes, "It is the business of philosophy [...] to make it possible for us to get a clear view of the conceptual structure that troubles us: the state of affairs before the contradiction is resolved" (Ibid, p. 334). Hacker reads Wittgenstein as taking the business of 
philosophy to be the assembling of rules for the uses of words, and the exploration of the ways in which our concepts hang together. The important point, as he sees it, is that these rules and mappings are such that everyone would acknowledge them. Hacker sees nothing either dogmatic, or intrinsically conservative, in this exercise (cf. Hacker, 2007, p. 105).

This positive aspect of philosophical investigation introduces a certain systematisation into philosophy which Hacker is careful to distinguish from the systematisation to be found in science. This positive aspect is not to be confused with the construction of theories - whether scientific or philosophical. Rather, philosophers should aim to provide thorough surveys of the sources of error and confusion, they should give methodical descriptions of segments of grammar (cf. 2001, p. 342; and also 1986, vi., 6). Hacker takes this to count as being systematic in philosophy - but this is not the systematisation of theory building and it should not be take to be knowledge accumulation (1986, p. 178). Hacker reads Wittgenstein as distinguishing between the amassing of knowledge in science and the achievement of understanding in philosophy (Hacker, 2001, p. 324). Thus, Hacker allows that Wittgenstein aims to solve problems in his work (Ibid, p. 336), and he believes he is following Wittgenstein when he writes: "Philosophy is neither the queen of the sciences nor their under-labourer, but is rather the tribunal of sense" (Ibid, p. 343). Philosophy plays this important role through careful attention to the use of language. In one place Hacker writes: "This may appear to trivialize a profound subject to a matter of mere words. But [...] there is nothing trivial about language. We are essentially languageusing creatures.' Language, he says, moulds our nature, informs our thought, and infuses our lives (1997, pp. 11-12).

The idea that Wittgenstein's work should be read as containing a negative and a positive "aspect" is something fiercely contested by Gordon Baker.

Baker was a one-time collaborator with Hacker, and together they published several important volumes devoted to the interpretation of Wittgenstein's work. But Baker, in his mid-to-late career, found himself in deep disagreement with Hacker's (and his own earlier) interpretation of Wittgenstein. Much of this disagreement can be focussed on Baker's rejection of what Hacker identifies as a positive and a negative aspect in Wittgenstein's later work.

In PI 122 Wittgenstein writes: "A main source of our failure to understand is that we do not command a clear view of [übersehen] the use of our words." Baker teases out different understandings of what Wittgenstein might mean here. One understanding he labels the "Birds Eye View Model", and he claims this represents what Hacker identifies in his positive, systematic, aspect of the business of philosophy. Baker rejects this view precisely because of its aim of systematisation, of providing a "logical geography" of concepts. Baker understands the avowed aim of this view as aiming to obtain "a kind of synoptic view without getting lost in the details" and to obtain this by delineating "the salient logical articulations forged by grammar, the central structure of the net of language, not the local refinements" (Baker \& Hacker, 1980, p. 543). Baker came to see this project as a mistaken understanding of PI 122, one that turns its back on the very thing it should be embracing: drawing attention to differences in our use of words. Philosophy, Baker now insists, is about drawing attention to "hidden aspects" or unnoticed patterns in the use of our words (Baker, 2004, p. 41). 
Baker's understanding of the way in which philosophy draws attention to neglected aspects of the uses of our words also brings him into conflict with Hacker. There are references dotted throughout Wittgenstein's later writing to the idea of philosophy as a form of therapy. Consider, for example, PI 255: "The philosopher's treatment of a question is like the treatment of an illness." In PI 113 Wittgenstein emphasizes that, although philosophy does not have a single method of proceeding, one can identify various methods, "like different therapies".

Hacker acknowledges references to therapy and to psychoanalysis in Wittgenstein's writings, but he insists that Wittgenstein only intended us to understand an analogy here and that this analogy does not play an important part in the understanding of method in philosophy. Hacker insists that the confusions that Wittgenstein is concerned to head off with his method are not targeted at individual patients (as is the case in psychoanalysis) so much as at schools of thought or ways of thinking that one finds in philosophy. He writes, "Wittgenstein did not open the Investigations with a quotation from St Augustine because he was concerned with Augustine's tormented confusions" (Hacker, 2007, p. 101). According to Hacker, what concerned Wittgenstein was a certain conception of language and the importance of the reference to Augustine comes from the fact that certain conceptions can be found even in an account of language-learning, such as Augustine's, which is not intended to be speculative or theoretical, but simple as a plain statement of language learning. As Hacker reads him, Wittgenstein places more emphasis on, for example, the method of reminding people that they really use words in such and such a way (see Hacker, 2007, p. 100).

Baker, on the other hand, understands these references to therapy as crucial to understanding Wittgenstein's method in philosophy. The centrality and importance of therapy in Wittgenstein's work, he argues, goes hand and hand with Wittgenstein's method of drawing attention to the neglected aspects of the uses of our words. Baker writes at one point: “Accepting Wittgenstein's methods of therapy as a form of philosophical investigation presupposes reconceptualising the boundary between logic and psychology" (Baker, 2004, p. 219). What Baker takes Wittgenstein to be concerned with, when looking at the uses of sentences, is what the speaker of those sentences has in mind when uttering them (Baker, 2004, p. 208). We look at what the speaker is trying to say, we observe the puzzling things he does say, and we direct his attention to how those words are used in everyday life. We do this by offering to change his aspect on his use of his word, and we do this with the use of analogies, comparisons, pictures, and the like. As Baker reads him, Wittgenstein sees philosophical problems as "deep disquiets" on the part of individuals (ibid, p. 213). It follows that the role of philosophy is a therapeutic one, and this does not stand in contrast to any other role.

The stark contrast between these two interpretations of Wittgenstein's later work can be seen if we look at what they have to say about psychological concepts. While Baker takes Hacker to understand Wittgenstein as urging that philosophers discern "the genealogical tree of psychological concepts", Baker himself understands Wittgenstein to urge that philosophers discern the variety of language games to which these psychological concepts belong and to which "new joints" are added (Baker, 
2004, p. 47). Baker understands the "clear view" of which Wittgenstein writes in PI 122 as "a view from nowhere", which should not be confused with any particular way of seeing things (ibid). Baker writes: "Wittgenstein advocated nothing more (and thing less!) than different possible ways of looking at things" (ibid, p. 45). Baker does not read Wittgenstein as advocating another way of doing philosophy, but rather as simply pointing out the many different ways in which our words are "integrated into human activity" (ibid, p. 78).

Baker's understanding of Wittgenstein's method in his later philosophy extends to an understanding of PI 116, quoted above: "What we do is to bring words back from their metaphysical to their everyday use". Baker notes, not unreasonably, that this passage has often been cited as "decisive textual evidence" for the assimilation of Wittgenstein's later work with that of OLP (Baker, 2004, p. 94), and Baker suggests that this assimilation partly explains why Wittgenstein's work has "been relegated to the sidelines in contemporary analytic philosophy" (ibid, p. 105). Baker takes this assimilation to be in error and believes that appreciation of this might help to bring Wittgenstein's work in from the sidelines. Baker reminds us of the traditional conception of metaphysics as a science of essences, and he agrees that there is a clear emphasis in Wittgenstein's later work on the idea that philosophy should turn its back on this business. What Baker thinks is less clear is whether we should understand reference to "everyday use" in PI 122 as a reference to ordinary language. In particular, Baker questions whether we really do find in Wittgenstein's later work an idea that philosophy should concern itself with the surveying and mapping of ordinary language. As Baker reads PI 122, "every day" is to be read as simply equivalent to "non-metaphysical" (ibid, p. 92). And as Wittgenstein draws our attention away from the metaphysical use of language he draws it to the myriad of possibilities that exist in our language - possibilities that cut against the metaphysical search for essence. We must resist the idea that language must be a certain way. Baker writes, "No claim is made that this [non-metaphysical] use is sacrosanct, or that we have no right to depart from it" (ibid, p. 103). Baker takes it to be a mistake to put any emphasis on the everyday or ordinary use of language.

Baker's work on the later-Wittgenstein has opened up new avenues of exploration and debate, and at the heart of this debate we can identify the issue of Wittgenstein's standing as an ordinary language philosopher. Of course, whether Baker is right to distinguish between Wittgenstein and the other so-called ordinary language philosophers will depend not just on his interpretation of Wittgenstein's later work but also on an examination of the work of these other philosophers. Avner Baz and Alice Crary advocate that we read Wittgenstein's work in a new light (arguably akin to that in which Baker reads it), but they also urge us to read Austin's work in this light.

Thus we see that Baker is not the only philosopher in recent times to have opened up fresh avenues for debate. Within the world of Wittgenstein scholarship there is a group that has come to be known as "the new Wittgensteinians". Just as the label "ordinary language philosophy" can be thought to bring together a range of different ideas, so the work here referred to also brings together a variety of new ideas in Wittgenstein scholarship. As well as those mentioned above, the names associated with this movement include J. Conant, O. Kuusela, M. McGinn, and R. Read. Inspiration for this work comes from such philosophers as S. Cavell, C. Diamond, and J. McDowell. 
One strand in this new work in Wittgenstein interpretation relates directly to our discussion of Wittgenstein's relationship to ordinary language philosophy. McGinn and Kuusela accept the thought, prevalent in this "new" literature, that there is less of a discontinuity between Wittgenstein's early and later work than earlier commentators generally supposed. They argue that Wittgenstein, in his later work, comes to reject only the idea that there is $a$ logic of language. What they take Wittgenstein to have come later to appreciate is that formal logical methods can also be "complemented with other methods of conceptual, grammatical, or logical clarification that take into account other aspects of language besides its rule-governedness..." (2011, p. 6). (How close this understanding comes to ideas explored by Baker is hard to assess, in part because Baker confines his remarks to an interpretation of the later works of Wittgenstein.) McGinn and Kuusela suggest that, if they are correct in their interpretation, then not only is there an underlying unity to Wittgenstein's work, but one can point to this in an attempt to uncover an underlying unity within analytical philosophy itself. In particular, they suggest that there need not be a perceived conflict between "the scientific aspirations of analytic philosophy and [a commitment to] common sense" (ibid). Some, following this line of thought, have suggested that science should be thought of as one way in which we ordinarily use language. (see, for example, Read 2010).

The question of the business of philosophy, and its relationship to the business of science are matters of deep importance to the academic and intellectual life of the community. One issue that these questions touch on is this: is our study of use confined to what we do at present, or can it be expanded to incorporate new and creative extensions of use? Baz suggests that the important contrast is between use that serves the purposes of the speaker and use that undermines these purposes - the former is genuine, while the latter is only apparent use (Baz, 2012, p. 3). If we look back to the writing of Cavell, someone to whom Baz is indebted, we find an interesting observation. Cavell claims that when we read in the work of Wittgenstein and Austin references to "what we ordinarily say" the emphasis is not so much on the "ordinariness" of our words but on the "we" who use them. Human beings share, not just a language, but a nature. While we might agree that language evolves through use, we must also acknowledge that this evolution is ultimately answerable to the agreement of those who use it - and that agreement will ultimately be determined by the nature of those language users. (cf. Zettel 318: "The teacher will sometimes say "That's right'. If the pupil should ask, 'Why?' - he will answer nothing or at any rate nothing relevant, not even 'Well, because we all do it like that; that will not be a reason"). According to Cavell what Wittgenstein and some other so-called ordinary language philosophers aim to do is "put the human animal back into language and thereby back into philosophy" (1979, p. 207).

While there has been a tendency in philosophy as it is practiced today to confine the work of both Wittgenstein and the 'ordinary language philosophers' to a particular moment in the history of philosophy, I have tried to demonstrate the continued relevance and importance of this work to philosophy. The question of what is the business of philosophy is itself an important philosophical question. 


\section{BIBLIOGRAPHY}

Austin, J. (1979), Philosophical Papers ( $3^{\text {rd }}$ edition), Oxford, Oxford University Press. Austin, J. (1979), “A Plea for Excuses”, in Philosophical Papers ( $3^{\text {rd }}$ edition).

Austin, J. (1956), "Ifs and Cans", in Philosophical Papers $\left(3^{\text {rd }}\right.$ edition $)$

Baker, G., (2004), "Philosophical Investigations 122: Neglected Aspects", in Wittgenstein's Method: Neglected Aspects, K. Morris ed., Oxford, Blackwell Publishing

Baker, G. and Hacker, P. (1980), Wittgenstein Understanding and Meaning, Oxford, Basil Blackwell.

Baz, A. (2012), When Words are Called For, Cambridge, Mass., Harvard University Press.

Cavell, S. (1979), "Excurses in Wittgenstein's Vision of Language", in The Claim of Reason, Oxford, Oxford University Press.

Dummett, M. (1973), The Seas of Language, Oxford, Clarendon Press.

Dummett, M. (1978), Truth and Other Enigmas, Cambridge, Massachusetts, Harvard University Press.

Grice, H.P. (1989), "Logic and Conversation", in Studies in the Way of Words, Cambridge, Massachusetts, Harvard University Press.

Hacker, P. (1986), Insight and Illusion, revised edition, Oxford, Clarendon Press.

Hacker, P. (1996), Wittgenstein's Place in $20^{\text {th }}$ Century Analytic Philosophy, Oxford: Blackwell

Hacker, P. (1997), Wittgenstein On Human Nature, Great Britain, Phoenix.

Hacker P. (2001), "Philosophy", in Wittgenstein: A Critical Reader, Hans-Johann Glock ed., Oxford: Blackwell.

Hacker, P. (2007), “Gordon Baker's Late Interpretation of Wittgenstein”, in G.

Kahane, E. Kanterian, and O. Kuusela eds., Wittgenstein and his Interpreters, Oxford: Blackwell Publishing, pp. $88-123$.

Hanfling, O. (2000), Philosophy and Ordinary Language, London and New York: Routledge.

Heil, J. (1995), “ordinary language philosophy”, in R. Audi, general editor, The Cambridge Dictionary of Philosophy, Cambridge, Cambridge University Press, p. 551. 
Hume, D. (1975), An Enquiry concerning Human Understanding and concerning the Principles of Morals, third edition, with text revised and notes by PH. Nidditch, Oxford, Oxford University Press.

Martinich, A.P. (1998), “Ordinary Language Philosophy”, in E. Craig, general editor, The Routledge Encyclopedia of Philosophy, London, Routledge, pp. 143 - 147.

McGinn, M. (1997), Wittgenstein and the Philosophical Investigations, London \& New York, Routledge.

McGinn, M and Kuusela, O. (2011), The Oxford Handbook of Wittgenstein, Oxford: Oxford University Press.

Pears, D. (1971), Wittgenstein, Great Britain: Fontana/Collins.

Read, R. (2010), “Ordinary/Everyday Language”, in Wittgenstein: Key Concepts, K.D. Jolley, ed., Durham, Acumen.

Warnock, G. (1998), “Ordinary Language Philosophy”, in E. Craig, general editor, The Routledge Encyclopedia of Philosophy, London, Routledge, pp. 147 - 153.

Von Wright, G.H. (1982), "Wittgenstein in relation to his Times", in Wittgenstein and his Times, B. McGuinness (ed.), Oxford: Basil Blackwell, pp. $108-121$.

Wittgenstein, L. (1951), Tractatus Logico-Philosophicus, trans. by C.K. Ogden, London, Routledge \& Kegan Paul.

Wittgenstein, L. (1967), Zettel, edited by G.H. von Wright, trans. by G.E.M. Anscombe, Oxford, Blackwell.

Wittgenstein, L. (1958a), The Blue and Brown Books, Preliminary Studies for the Philosophical Investigations, New York, Harper \& Row Publishers.

Wittgenstein, L. (1958), Philosophical Investigations, $3^{\text {rd }}$ edition, trans. by G. E. M. Anscombe, New York: The Macmillan Company.

Wittgenstein, L. (1968), “Wittgenstein's Notes for Lectures on 'Private Experience' and 'Sense Data', Philosophical Review, July, pp. 271 - 320.

Anita Avramides

Southover Manor Trust Fellow and Reader in Philosophy of Mind

St Hilda's College, Oxford 
